\title{
The role of quality of work life in Jordanian hotel industry
}

\author{
Bandar Ersan Alown ${ }^{a^{*}}$, Fu'ad Abdallah Al-fakeh ${ }^{\text {b }}$ and Asad Aburumman ${ }^{c}$
}

${ }^{a}$ Department of Economic, Universiti Sultan Zainal Abadin (UNISZA), Malaysia

${ }^{b}$ Department of Economic, University Malaysia Terengganu (UMT), Malaysia

${ }^{c}$ Department of Tourism Guidance, University of Sharjah, United Arab Emirates

\section{H R O N I C L E}

\section{Article history:}

Received: June 20, 2020

Received in revised format:

August 302020

Accepted: September 18, 2020

Available online:

September 23, 2020

Keywords:

Job Satisfaction

Quality of work life

Hotel

Jordan

\section{A B S T R A C T}

Success key elements are crucial for the improvement and preservation of competitiveness in the hotel sector. Hotels thus need efficient employees with best possible quality of work life to remain competitive. This paper investigated the impact of organisational structure (OS) and leadership style (LS) on quality of work life (QWL) among five-star hotels employees in Jordan with job satisfaction (JS) as mediator. Questionnaires were distributed among 430 five-star hotel employees to obtain the study data. The levels of relationships among the constructs (OS, LS, JS, and QWL) were analysed using partial least squares structural equation modelling (PL-SEM). The results showed a positive relationship of JS and OS with QWL, while JS showed a partial mediating role on the relationship among LS, OS and QWL. Similar studies should be carried out on other sectors in Jordan and in other settings using different perspectives.

\section{Introduction}

The world today is competitive and businesses including the hotel industry depend on their employees to succeed. Employees are indeed assets to organisations as they are the ones who drive the profit. As such, job satisfaction and quality of work life of employees are a significant concern to organisations. Accordingly, Theory of Service Chain Profit (Heskett \& Schlesinger, 1994), suggests the importance of employee satisfaction in profit generation especially in the service industry. Mohamad, Ghani, Mamat and Mamat (2014) indicated that satisfied and happy employees towards their work will happily handle the customers and fulfil their expectations. The sector of tourism is important in Jordan as it brings in large amount of foreign exchange resources for the treasury. In 2016 for instance, the overall input of Travel and Tourism to GDP in this country was reported at USD7, 640.7 million, amounting to 19.4\% of GDP (WTTC, 2017). Relevantly, Jordan's Vision 2020 aspires to establish a comprehensive, world-standard tourism industry that can significantly drive the country's development, foster income equality nationwide while influencing the government investment policy and indorsing the country as a destination of choice (USAID, 2018). Jordan also aspires to provide a sustainably managed environment. Additionally, in Amman and Aqaba, the upscale hotels are facing human resources related problems, and these include stress among employees, lack of qualified workforce, and high employment rate (Alown, Mohamad \& Karim, 2020). Additionally, these hotels are facing several issues associated with their core operation processes such as high competition, seasonality, and high expectations from customers (Montgomery, 2017). All of these, according to Kelloway and Myers (2019), can decrease the general job satisfaction and work life quality of employees especially those in the Front-Line. Safavi and Karatepe (2018) further added that globalization, intensified competition, higher customer turnover, and increase in customer expectations and customer acquisition costs are among the challenges that the hotel industry has to face. This shows that within the context of hotels, competitiveness and quality of work life are highly affected by the hotels' competency in effectively and efficiently satisfying the

* Corresponding author.

E-mail address: bandaraloun@gmail.com (B. E. Alown) 
customers. Hence, the responsible parties should address these issues and come up with some innovative solutions. In this context, upscale Jordanian hotels in Amman and Aqaba are ideal for this study in investigating the impact of job satisfaction on the quality of work life.

\section{Literature review and hypotheses development}

\section{Quality of Work Life}

Within the context of healthcare, the concept of quality of work life (QWL) was defined in Brooks and Anderson (2005) as the level to which registered employees are able to fulfil crucial personal needs via their expectations in their work organisations while accomplishing the goals set by the organisation. Meanwhile, QWL was described by Argentero, Miglioretti, and Angilletta (2007) as the evaluation outcome attained by individual from making comparison between his/her hopes, expectations and desires, and what the individual think as reality. In providing the definition of the concept, some utilized a broad scope while some were referring to certain fields or context of work life. The concept of QWL has been considered in various aspects including movement, a set of organisational intervention and a type of life that employees experience while performing their tasks. Notably, there is no universal definition for QWL because it is context-based and complex. Hence, within the setting of Jordan, this study describes the concept of QWL as the degree to which the structures of workplace allow the employees of hotel to meet their individual expectations while accomplishing the objectives set by the organization. Meanwhile, in the hospitality industry, hotel employees encompass the biggest group and they are considered as the Front-Line work force, which denotes their importance in assuring the quality of hotel services and in improving customer satisfaction. Within tertiary Jordanian hotels, it is important that the employees have high QWL.

\section{Job Satisfaction}

Job satisfaction has various definitions. In Ghaith and Mutia (2019), job satisfaction refers to the happiness felt by employees toward a given job, while in Spector (1997), job satisfaction refers to the level of like or dislike felt by employees towards their jobs. Based on these definitions, job satisfaction can be regarded as the relationship perception between what employees offer and what they expect to attain from their job. Van Wyk, Swarts and Mukonza (2018) relevantly reported that job satisfaction decreases absenteeism and boredom among employees. Further, Chirchir (2016) mentioned the demographic characteristic of employees as among the factors that inform satisfaction in employees. Job satisfaction has also been described as the inner peace and pleasure that an individual feel in the workplace. The direct link between job satisfaction and work environment, organisation practices and management has been reported in Bari, Fanchen, and Baloch (2016). Furthermore, Joo and Lee (2017) mentioned in their study that job satisfaction of employee is likely to be exhibited in the general happiness that they feel in the workplace. Pertinently, a job satisfaction model was proposed in Ghaith and Mutia (2019) in their examination of the response of five-star hotel employees in Jordan whereby the model includes the variables of behaviour. Notably, the hotels under study offered high monetary benefits and secure work environment and low monetary benefits. From the results, the authors indicated the impact of different behavioural variables (e.g., leadership style, commitment, and organisational culture) on job satisfaction. Also, the results showed that increased rewards do not enhance employees' dissatisfaction level.

\section{Leadership Style}

The concept of leadership has been presented by various definitions and models (Ledlow \& Coppola, 2013). In Northouse (2018), leadership was described as the ability of a person in influencing and providing guidance to followers in the accomplishment of a mutual goal. Meanwhile, Yukl, Gordon, and Taber (2002) presented the concept of leadership as a process of influencing followers to come to an understanding and agreement to work hand in hand to reach the common objectives. Meanwhile, leadership has drastically evolved over the years. In fact, various styles of leadership have emerged as discussed next. Employees who feel forced to remain in relationship with the organisation have no work flexibility and this can cause them to lose interest in their tasks. If this occurs, the employees can become uncommitted towards the organisation. Hence, to main competitive edge, the organisation needs make efforts to prevent talent loss. In doing so, Afsar, Badir and Saeed (2014) mentioned the need for managers to embrace a leadership type that could lead to the improvement of commitment of employees. Accordingly, an effective leader is one with the ability in expressing a vision, in instilling trust, belief and loyalty, and also in directly guiding the talents of employees towards the accomplishment of the organisational goals (Lian \& Tui, 2012; Shadraconis, 2013).

\section{Organisational Structure}

An organisational structure apportions the entire organisation into distinguishable portions. It also delineates the relationships among these portions. The apportionment specifies the accountability of each involved individual - who is responsible for what, who has authority over whom or what, and so forth (Mendibil, Rudberg, Baines, \& Errasti, 2016). Mansoor, Aslam, Barbu, Capusneanu and Lodhi (2012) indicated that the chain of command and accountability is manifested by the organisational structure. In Teixeira, Koufteros, and Peng (2012), organisational structure was considered as an instrument for the integrated utilization of the presently available resources inside the organisation. Mendibil et al. (2016) relevantly indicated that the organisation structure designing is more than merely presenting the relationships among parts. Equally, organisation structure demonstrates the resources, systems, culture, in addition to other necessary features in supporting the structure. 


\section{Leadership Style and Job Satisfaction}

The link between leadership styles and job satisfaction has been empirically examined in several studies (e.g., Bass \& Riggio, 2006; Menon, 2014; Griffin \& Bateman, 1986; Lian \& Tui, 2012; Nguni, Sleegers, \& Denessen, 2006) and it was reported that leadership behaviour is an important predictor of job satisfaction. In their study, Howell and Dorfman (1986) reported the direct impact of leadership behaviours on job satisfaction among employees, their loyalty towards the organisation, work pressure, motivation and team cohesion; all of these affect performances. In, Lashbrook (1997) it was found that leadership style greatly impacts job satisfaction of employees. Also, leadership style and job satisfaction appear to be linked in private sector (Griffith, 2004; Heller, Clay, \& Perkins, 1993; Judge \& Piccolo, 2004; Mckee, 1991; Silins \& Mulford, 2002; Walumbwa, Orwa, Wang, \& Lawler, 2005), leading to the view that leaders significantly impact job satisfaction of their employees. As such, the hypothesis below is put forward:

$\mathrm{H}_{1}$ : Leadership style has a positive impact on job satisfaction.

\section{Organisational Structure and Job Satisfaction}

Job satisfaction was discussed in Buchanan and Huczynski (2019) as an established general attitude resulting from certain job factors, individual characteristics, and relationships beyond the job. Equally, it encompasses the general attitude of a person toward his job, which is also theorized as personalistic condition assessments of job, supervision, or outcomes resulting from having a job (Turkina, Assche \& Kali, 2016; Al-Adamat, Al-Gasawneh \& Al-Adamat, 2020). Meanwhile, among organisational behaviourists and professionals of human resources, there has been an interest towards the most fitting way for structuring a work environment for influencing the outcomes of employee through the achievement of job satisfaction. As relevantly indicated in some studies including Joseph and Gaba (2020) and Aburumman, Salleh, Omar and Abadi (2020), the attitudes of people, in this context, employees, are affected by organisational structure, such as the personal preferences of managers in preserving the relationship with subordinates and other managers, and the ways utilized in handling problems. Ahmady, Mehrpour and Nikooravesh (2016) described organisational structure as task arrangement, interrelations of different departments and authority levels, for the accomplishment of collaboration of efforts, authority designation and effective communication along the scalar chain of command. Aside from providing the description on the formal division, grouping, and coordination of job tasks, structure illustrates the hierarchical relationships among organisation members. Furthermore, achieving the highest possible level or most optimal productivity is the aim of almost all organisations. Hence, this study presents the following hypothesis to be tested:

$\mathrm{H}_{2}$ : Organisational structure has a positive impact on job satisfaction.

\section{Job Satisfaction and Quality of Work Life}

QWL is partly characterized by satisfaction of employees (Shan, Imran, Lewis, \& Zhai, 2017). Furthermore, in their studies, Sinha and Shukla (2012), Mazloumi, Kazemi, Nasl-Saraji, and Barideh (2014), Swamy, Nanjundeswaraswamy, and Rashmi (2015), as well as Almarshad (2015) utilized job satisfaction as a QWL dimension. In fact, the use of QWL as a measure of job satisfaction is common in studies. QWL is a factor to job satisfaction, and as empirically proven in Hassan and Ibrahim (2020) and Kim, Woo, Uysal and Kwon (2018), QWL leads to employees' work responses including: job satisfaction, organisational identification, job effort, job performance, job involvement, and organisational turnover. QWL and job satisfaction are two distinctive constructs (Jabeen, Friesen \& Ghoudi, 2018; Srivastava, Misra, \& Madan, 2019; Moafimadani \& Khalatbari, 2019), Mohamad, 2012; Al-Gasawneh \& Al-Adamat, 2020; Hamidi et al., 2019), and QWL has been found to lead to job satisfaction. Hence, this study puts forth the following hypothesis to be tested:

$\mathrm{H}_{3}$ : Job satisfaction has a positive impact on quality of work life.

\section{Job Satisfaction as Mediation}

Among industrial psychologists and management scholars, there has been an agreement that job satisfaction (JS) relates to the well-being of employees, while QWL is distinct from job satisfaction (Agarwal, Garg, \& Rastogi, 2019; Alrawadieh, Cetin, Dincer, \& Istanbullu Dincer, 2020; Karatepe \& Avci, 2017). As reported, aside from affecting QWL, job satisfaction also affects satisfaction in other areas of life including personal and family life (among others). Job satisfaction thus covers more than quality of work life. According to Ajala (2013) and Sethi (2012), job satisfaction also relates to the impact of the workplace on satisfaction with job, satisfaction in non-work areas of life, in addition to satisfaction with the general life, personal happiness and subjective well-being. The present study presents job satisfaction as the mediator between leadership style, organisational structure and quality of work life. It was pertinently indicated in Noblet, Allisey, Nielsen, Cotton, LaMontagne and Page (2017) that in dealing with diverse demands of job, it is important to establish new resources while also utilizing the presently available ones. Among the common work resources are job rewards including job security, promotion opportunities, and satiating relationship with customers, and job rewards can facilitate in decreasing work stress (Lafrenz et al., 2018). This study accordingly regards job satisfaction as a resource that is of value to employees. Additionally, as mentioned in Ramawickrama et al. (2017), job satisfaction is associated with the satisfaction of employees towards various needs, and these needs include need to utilize skills, social needs and need of esteem (among others). Utilizing conservation of 
resources theory in their study, Al-Ababneh, Al-Sabi, Al-Shakhsheer and Masadeh (2017) reported the mediation effect of satisfying work relations and job conditions on the relationship between leadership style, organisational structure and quality of work life among employees of Jordanian hotels. As such, the following hypothesis is presented to be tested.

$\mathrm{H}_{4}$ : Job satisfaction mediates the relationship between leadership style, organisational structure and quality of work life.

\section{Application resource-based view (RBV) theory}

In this study, quality of work life including organisational structure and leadership style on quality of work-life relationships is examined with job satisfaction as mediator. In this regard, the presented constructs may be regarded as unique intangible resources (i.e., leadership, organisational structure, quality of work-life) that Jordanian five-star Hotels can utilize in distinguishing themselves from their competitors. Utilizing Resource based view theory (RBV), Barney, Wright and Ketchen (2001) indicated that organisational structure is reflected within the practices and procedures used in the organisation. The authors further mentioned the temporariness of such structure, under close control, with its perceivably restricted aspects among members. Organisational structure is hence easily impacted, and the resulting changes that occur within the structure may be discernible over a short duration. Organisational structure is thus arguably a distinctive intangible resource usable by the organisation in achieving competitive advantage.

\section{Methodology}

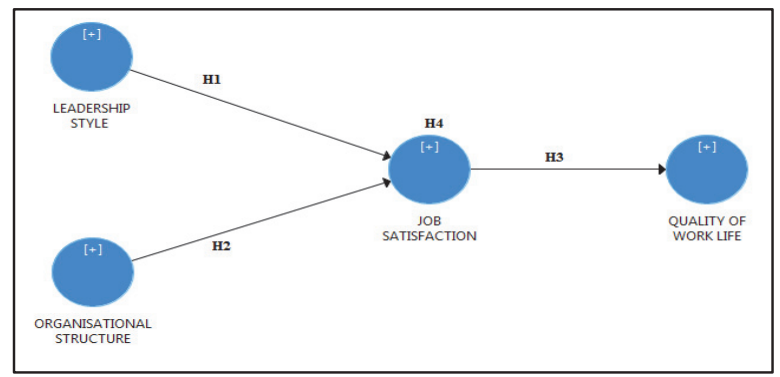

Fig. 1. Research Model

This descriptive study illustrates a phenomenon or specific condition that portrays the existing situation, which allows decision making. Such study aims to affirm the related hypothesis developed earlier. For primary data collection, this study employed questionnaire survey, and simple random sampling method was used in selecting the respondents. A total of 449 frontline employees in the Jordanian hotel's industry took part in this study in answering the questionnaires, and 430 of these employees returned the questionnaires (96\% response rate). According to Sekaran and Bougie (2016), a response rate in survey studies should be at least $30 \%$ to be considered as sufficient, and thus, this study has sufficient response rate. Measurements of constructs from past studies were used in the questionnaires. The 13 items that represent quality of work life were adapted from Sajtos et al. (2015), the 5 items that represent job satisfaction were adapted from Hassi (2012), the 5 items that denote leadership style were from Sanda and Arthur (2017), and the 5 items representing organizational structure were based on Valaei (2017). The items were equipped with 10-point Likert scales each. This study carried out pilot test involving 100 frontline employees of Jordanian hotels in Amman and Aqaba. Hotels in Amman and Aqaba were chosen in selecting pilot study respondents owing to the similarity of their background to the 21 selected hotels in the actual study. Similar approach was used for the gathered pilot study data. Details are presented in Table 1.

Table 1

Pilot Test Results

\begin{tabular}{lccccc}
\hline Construct & No. of Items & KMO & Cronbach's Alpha & Cumulative \% & Sig. \\
\hline QWL & 13 & .952 & .948 & .000 & 73.30 \\
JS & 5 & .885 & .927 & 77.40 \\
LS & 5 & .721 & .986 & 900 & .000 \\
OS & 5 & .887 & .949 & .68 & 84.09 \\
\hline
\end{tabular}

Validity and reliability of the questionnaire were assured in this study, and in doing so, feedbacks were sought from academic experts (professors at universities) in order that necessary changes could be made to the questionnaire. Another step-in assuring validity and reliability of the questionnaire was to test the internal consistency through the use of Cronbach alpha for the variables. Hair (2017) proposed the use of sample size of more than 100 in order to assure accurateness of results. Hence, this study needed to distribute 330 questionnaires. Table 1 accordingly presents the variables in the study, particularly the item numbers and sources of revised scales. PLS-SEM software was used for data analysis. As mentioned, a 10-point rating scale was used ranging from 1 to represent "strongly disagrees", to 10 to represent "strongly agrees," and such range has been mentioned by in Awang, Afthanorhan and Asri (2015) as fitting. Furthermore, the interval scale encompasses a constant score and it also fulfils the requirement for the utilization of parametric statistical analysis. The 10-point rating scale has been used in many studies particularly in structural equation modelling (Chen, 2013; Curşeu et al., 2007; Delahaij, Gaillard, \& van Dam, 
2010). Based on Zikmund and Griggen (2013), the present study determined the items of questionnaire based on the conceptual finding and explanation in the extant literature, and modified the items according to the study objectives. Table 2 can be referred.

Table 2

Scales Used in Research

\begin{tabular}{lcll}
\hline Construct & No. of items & Adapted from & Scale \\
\hline Quality of work life & 13 & Sajtos et al. (2015) \\
Job satisfaction & 5 & Hassi (2012) & $1-10$ \\
Leadership style & 5 & Sanda \& Dodua (2017) \\
Organizational structure & 5 & Valaei (2017) & $1-10$ \\
\hline
\end{tabular}

\section{Results}

\subsection{Measurement Model}

This study employed 4 first-order constructs of LS, OS, JS, and QWL involving 23 items. Confirmatory factor analysis was used in measurement model evaluation. Fig. 2 displays the measurement model.

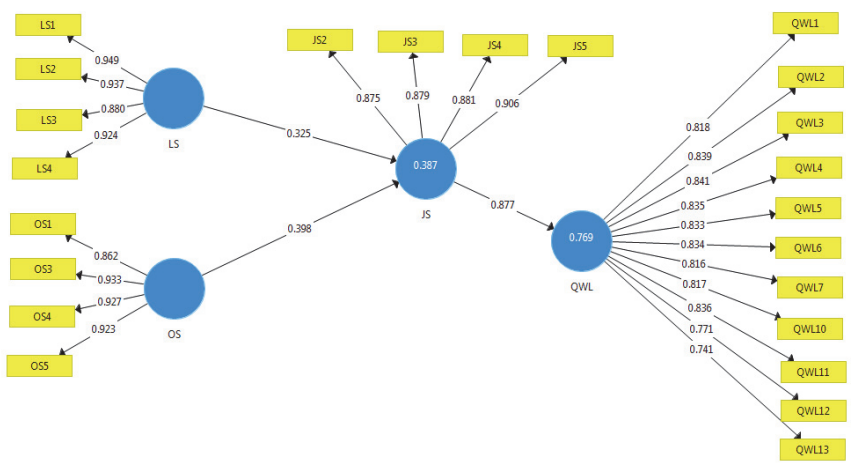

Fig. 2. The Measurement Model

\subsubsection{Convergent Validity}

Confirmatory factor analysis for the measurement model is displayed in Table 3. The table also displays the results of evaluation of the standardized factor loadings of the items in the model. As shown in the table, the standardized factor loadings were all greater than 0.6. As can be observed, the loadings fall in the range between 0.741 and 0.949 . Also, for all constructs, the AVE values fall in the range between 0.668 and 0.852. Based on the recommendation of Hair et al. (2017), all values are greater than the cut-off value of 0.5 . For all constructs, the composite reliability values fall in the range between 0.935 and 0.958, and as can be observed, the values are all above 0.7 as proposed in Hair et al. (2017) and Fornell and Larcker (1981).

Table 3

The Result of Cronbach's Alpha and Convergent Validity for the CFA Model on the Research Model

\begin{tabular}{|c|c|c|c|c|}
\hline Construct & Items & Factor Loading & $\mathrm{CR}$ & AVE \\
\hline \multirow{4}{*}{ Leadership Style } & LS1 & 0.949 & 0.958 & 0.852 \\
\hline & LS2 & 0.937 & & \\
\hline & LS3 & 0.880 & & \\
\hline & LS4 & 0.924 & & \\
\hline \multirow{4}{*}{ Organizational Structure } & OS1 & 0.862 & 0.952 & 0.831 \\
\hline & OS3 & 0.933 & & \\
\hline & OS4 & 0.927 & & \\
\hline & OS5 & 0.923 & & \\
\hline \multirow{4}{*}{ Job Satisfaction } & JS2 & 0.875 & 0.935 & 0.784 \\
\hline & JS3 & 0.879 & & \\
\hline & JS4 & 0.881 & & \\
\hline & JS5 & 0.906 & & \\
\hline \multirow{11}{*}{ Quality of Work Life } & QWL1 & 0.818 & 0.957 & 0.668 \\
\hline & QWL2 & 0.817 & & \\
\hline & QWL3 & 0.836 & & \\
\hline & QWL4 & 0.771 & & \\
\hline & QWL5 & 0.741 & & \\
\hline & QWL6 & 0.839 & & \\
\hline & QWL7 & 0.841 & & \\
\hline & QWL10 & 0.835 & & \\
\hline & QWL11 & 0.833 & & \\
\hline & QWL12 & 0.834 & & \\
\hline & QWL13 & 0.816 & & \\
\hline
\end{tabular}




\subsubsection{Discriminant validity}

Based on Henseler, Ringle and Sarstedt (2015), this study generated HTMT to establish the model's discriminant validity.

Table 4

The HTMT for constructs

\begin{tabular}{llll}
\hline & JS & LS & OS \\
\hline JS & & & OWL \\
LS & 0.537 & & \\
OS & 0.599 & 0.498 & 0.693 \\
QWL & 0.531 & 0.653 & 0.63 \\
\hline
\end{tabular}

As can be observed in Table 4, all HTMT values of the constructs were lower than 0.90. Specifically, the obtained HTMT values fall in the range between 0.498 and 0.693 . Based on Henseler et al. (2015), the HTMT values obtained in this study show that all latent construct measurements are fully discriminant against one another. This study thus affirmed the full reliability and validity of the measurement scale after investigating the convergent validity and discriminant validity of the measurement model. Hence, the measurement scale is appropriate for the evaluation of the constructs and their relative items in the CFA model.

\subsection{Assessment Structural Model}

Structural model assessment encompasses the coefficient of determination $\left(\mathrm{R}^{2}\right)$ and path coefficients, both of which are integral in Hypotheses Testing. As can be referred in Table 5, the $\mathrm{R}^{2}$ values for the endogenous latent variables in this study follow the recommendations of Schreiber, Nora, Stage, Barlow and King (2006), and based on these values, it can be affirmed that the structural model proposed in this study has predictive accuracy.

Table 5

The $\mathrm{R}^{2}$ Values for the Endogenous Latent Variables

\begin{tabular}{lll}
\hline Construct & $\mathrm{R}^{2}$ & $\mathrm{Q}^{2}$ \\
\hline JS & 0.387 & 0.299 \\
QWL & 0.769 & 0.497 \\
\hline
\end{tabular}

\subsection{Hypothesized Direct Effects of the Constructs in Structural Model}

PLS algorithm and bootstrapping techniques were used in this study for path coefficients (Hypotheses Testing), involving the application of Smart PLS version 3.2.8 with 5000 bootstrap samples.

Table 6

Hypothesized Direct Effects of Structural Model

\begin{tabular}{lllllll}
\hline Path & St. beta & SD & F $^{2}$ & VIF & T-value & P-value \\
\hline LS-JS & 0.325 & 0.042 & 0.133 & 1.293 & 7.723 & 0.000 \\
OS-JS & 0.398 & 0.042 & 0.200 & 1.293 & 9.549 & 0.000 \\
JS-QWL & 0.877 & 0.077 & 3.332 & 1.000 & 11.389 & 0.000 \\
\hline
\end{tabular}

The values of path coefficient and the results of bootstrapping for hypothesized relationships between the variables are displayed in Table 6 . As shown, the effect of leadership style on job satisfaction is direct and positive $(\beta=0.325 ; \mathrm{t}=7.723 ; \mathrm{p}<$ $0.001)$, as a result, $\mathrm{H} 1$ was supported. Similar effect can be observed for organisational structure and job satisfaction $(\beta=$ $0.398 ; \mathrm{t}=9.549 ; \mathrm{p}<0.01)$. Hence, $\mathrm{H} 2$ is supported. Meanwhile, job satisfaction shows a positive direct effect on quality of work life $(\beta=0.877 ; \mathrm{t}=11.389 ; \mathrm{p}<0.01)$, lending support to H3. Thus, it can be concluded that the environment of work of Front-Line employees in Jordanian hotels offers effective quality of work life.

\subsection{Indirect effect of the constructs}

From the bootstrapping outcomes displayed in Table 7, LS, OS on QWL impart indirect impact via JS and the impact is positive and significant statistically $(0.05$ level; $\beta=0.285$, T-value $=7.538, \mathrm{P}$-value $=0.000)$. Furthermore, the indirect effect of Boot Corrected did not straddle a 0 in between $(L L=0.216, U L=0.360)$. According to Preacher and Hayes (2004), this shows the presence of a mediation effect. From the results, the mediation effect was statistically significant, lending support to hypothesis $\mathrm{H} 4$.

Table 7

Results of Hypotheses Testing for the Mediation

\begin{tabular}{lllllll}
\hline Path & St. beta & SD & T-value & $2.5 \%$ & $97.50 \%$ & P-value \\
\hline LS-JS-QWL & 0.285 & 0.038 & 7.538 & 0.216 & 0.360 & 0.000 \\
OS-JS-QWL & 0.349 & 0.038 & 9.280 & 0.269 & 0.412 & 0.000 \\
\hline
\end{tabular}




\section{Conclusions and Future Directions}

Quality of work life of employee was the focal point of this study, and factors impacting quality of work life were examined. In this study, leadership style, organisational and job satisfaction were the examined factors. The results have shown significant positive impact of leadership style, organizational structure and job satisfaction on quality of work life of employee. The study adds to the body of knowledge through the use of job satisfaction as mediating factor, and from the results, this study concluded that job satisfaction partially mediated the relationship between leadership style, organisational structure and quality of work life of employees. The relationships were further solidified through Resource based view theory (RBV) as proposed in Barney, Wright and Ketchen (2001). Notably, all the constructs examined (leadership style, organisational structure, quality of work-life) may be perceived as distinctive intangible resources, and these resources may be utilized effectively among Jordanian five-star Hotels to distinguish themselves from the rivals. Within an organization, organisational structure is reflected within the main practices and procedures, and the structure is impermanent and under close control with restricted aspects perceived by the members. Hence, it is easy to change organisational structure and the resulting changes may be discernible over a brief duration. Equally, organisational structure can be regarded as an inimitable intangible resource which can be used by the organisation in achieving competitive advantage. Meanwhile, the proposed conceptual framework was analysed using partial least structural equation modelling (PLS-SEM). Additionally, a limitation of this study has been noted. Firstly, the results show that leadership style, organisational structure and job satisfaction illuminate approximately $76 \%$ of variations in quality of work life. This brings to the need to consider other factors in future related studies as this will expand the proposed model while also providing more illumination on the variance in problem behaviour. Among the factors to be considered are: organisational culture, emotional intelligence and organisational commitment.

\section{References}

Aburumman, O., Salleh, A., Omar, K., \& Abadi, M. (2020). The impact of human resource management practices and career satisfaction on employee's turnover intention. Management Science Letters, 10(3), 641-652.

Afsar, B., Badir, Y. F., \& Saeed, B. B. (2014). Transformational leadership and innovative work behavior. Industrial Management \& Data Systems, 114(8), 1270-1300, 2014.

Agarwal, S., Garg, P., \& Rastogi, R. (2019). Testing the reciprocal relationship between quality of work life and subjective well-being: a path analysis model. International Journal of Project Organisation and Management, 11(2), $140-153$.

Ahmady, G. A., Mehrpour, M., \& Nikooravesh, A. (2016). Organizational structure. Procedia-Social and Behavioral Sciences, 230, 455-462.

Ajala, E. M. (2013). Quality of work life and workers wellbeing: The industrial social workers approach. IFE Psychologia: An International Journal, 21(2), 46-56.

Al-Ababneh, M., Al-Sabi, S., Al-Shakhsheer, F., \& Masadeh, M. (2017). The influence of employee empowerment on employee job satisfaction in five-star hotels in Jordan. International Business Research, 10(3), 133.

Al-Adamat, A., Al-Gasawneh, J., \& Al-Adamat, O. (2020). The impact of moral intelligence on green purchase intention. Management Science Letters, 10(9), 2063-2070.

Al-Gasawneh, J. A., \& Al-Adamat, A. M. (2020). THE RELATIONSHIP BETWEEN PERCEIVED DESTINATION IMAGE, SOCIAL MEDIA INTERACTION AND TRAVEL INTENTIONS RELATING TO NEOM CITY. Academy of Strategic Management Journal, 19(2).

Almarshad, S. O. (2015). A measurement scale for evaluating quality of work life: conceptualization and empirical validation. Trends in Applied Sciences Research, 10(3), 143.

Alown, B. E., Mohamad, M., \& Karim, F. (2020). Structural Equation Modeling based Empirical Analysis: Direct and Indirect Effects of Job Satisfaction on Job Performance in Jordanian Five-Star Hotels. Journal of Tourism, Hospitality and Environment Management, 5(18), 133-151.

Alrawadieh, Z., Cetin, G., Dincer, M. Z., \& Istanbullu Dincer, F. (2020). The impact of emotional dissonance on quality of work life and life satisfaction of tour guides. The Service Industries Journal, 40(1-2), 50-64.

Argentero, P., Miglioretti, M., \& Angilletta, C. (2007). Quality of work life in a cohort of Italian health workers. Giornale Italiano di Medicina del Lavoro ed Ergonomia, 29(1 Suppl A), A50-4.

Awang, Z., Afthanorhan, W. M. A. W., \& Asri, M. A. M. (2015). Parametric and non-parametric approach in structural equation modeling (SEM): The application of bootstrapping. Modern Applied Science, 9(9), 58-67.

Bari, M. W., Fanchen, M., \& Baloch, M. A. (2016). TQM Soft practices and job satisfaction; mediating role of relational psychological contract. Procedia-Social and Behavioral Sciences, 235, 453-462.

Barney, J., Wright, M., \& Ketchen Jr, D. J. (2001). The resource-based view of the firm: Ten years after 1991. Journal of Management, 27(6), 625-641.

Bass, B. M., \& Riggio, R. E. (2006). Transformational leadership. Psychology press.

Brooks, B. A., \& Anderson, M. A. (2005). Defining quality of nursing work life. Nursing Economics, 23(6), 319-326.

Buchanan, D. A., \& Huczynski, A. A. (2019). Organizational behavior. Pearson UK.

Chen, X. (2013). Instrumental traditions and theories of light: The uses of instruments in the optical revolution (Vol. 9). Springer Science \& Business Media.

Chirchir, R. (2016). Demographic factors and job satisfaction: A case of teachers in public primary schools in Bomet County, Kenya. Journal of Education and Practice, 7(13), 152-158. 
Curşeu, P. L., Stoop, R., \& Schalk, R. (2007). Prejudice toward immigrant workers among Dutch employees: Integrated threat theory revisited. European Journal of Social Psychology, 37(1), 125-140.

Delahaij, R., Gaillard, A. W., \& van Dam, K. (2010). Hardiness and the response to stressful situations: Investigating mediating processes. Personality and Individual differences, 49(5), 386-390.

Fornell, C., \& Larcker, D. F. (1981). Structural equation models with unobservable variables and measurement error: Algebra and statistics.

Griffin, R. W., Bateman, T. S., Cooper, C. L., \& Robertson, I. (1986). Job satisfaction and organizational commitment.

Griffith, J. (2004). Relation of principal transformational leadership to school staff job satisfaction, staff turnover, and school performance. Journal of Educational Administration, 42(3), 333-356.

Hair Jr, J. F., Sarstedt, M., Ringle, C. M., \& Gudergan, S. P. (2017). Advanced issues in partial least squares structural equation modeling. saGe publications.

Hamidi, S., Zandiatashbar, A., \& Bonakdar, A. (2019). The relationship between regional compactness and regional innovation capacity (RIC): Empirical evidence from a national study. Technological Forecasting and Social Change, 142, 394402.

Hassan, E. M., Fahmy, H. A., \& Hassan, M. I. (2020). Chemical composition, Rheological, Organoleptical and Quality Attributes of Gluten-Free Fino Bread. Egyptian Journal of Chemistry.

Hassi, A. (2012). The impact of culture on corporate training design: a review of the current state of knowledge. International Journal of Human Resources Development and Management, 12(1-2), 119-139.

Heller, H. W., Clay, R., \& Perkins, C. L. I. N. E. (1993). The relationship between teacher job satisfaction and principal leadership style. Journal of School Leadership, 3(1), 74-86.

Heskett, J. L., Jones, T. O., Loveman, G. W., Sasser, W. E., \& Schlesinger, L. A. (1994). Putting the service-profit chain to work. Harvard Business Review, 72(2), 164-174.

Howell, J. P., Dorfman, P. W., \& Kerr, S. (1986). Moderator variables in leadership research. Academy of Management Review, 11(1), 88-102.

Jabeen, F., Friesen, H. L., \& Ghoudi, K. (2018). Quality of work life of Emirati women and its influence on job satisfaction and turnover intention. Journal of Organizational Change Management.

Joo, B. K., \& Lee, I. (2017, August). Workplace happiness: work engagement, career satisfaction, and subjective well-being. In Evidence-based HRM: A Global Forum for Empirical Scholarship. Emerald Publishing Limited.

Joseph, J., \& Gaba, V. (2020). Organizational Structure, Information Processing, and Decision-Making: A Retrospective and Road Map for Research. Academy of Management Annals, 14(1), 267-302.

Judge, T. A., \& Piccolo, R. F. (2004). Transformational and transactional leadership: a meta-analytic test of their relative validity. Journal of Applied Psychology, 89(5), 755.

Karatepe, O. M., \& Avci, T. (2017). The effects of psychological capital and work engagement on nurses' lateness attitude and turnover intentions. Journal of Management Development.

Kelloway, E. K., \& Myers, V. (2019). Leading the service-profit chain: how leaders' behaviors can affect customer experience. Examining the Role of Well-being in the Marketing Discipline (Research in Occupational Stress and Well Being, Vol. 17), Emerald Publishing Limited, 71-90.

Kim, H. L., Woo, E., Uysal, M., \& Kwon, N. (2018). The effects of corporate social responsibility (CSR) on employee wellbeing in the hospitality industry. International Journal of Contemporary Hospitality Management.

Lafrenz, A., Lust, T., Cleveland, M., Mirka, A., Downs, A., Goodin, B., \& Van Hoomissen, J. (2018). Association between psychosocial and organizational factors and objectively measured sedentary behavior in desk-dependent office workers. Occupational Health Science, 2(4), 323-335.

Lashbrook, W. B. (1997). Business performance, employee satisfaction, and leadership practices. Performance Improvement, 36(5), 29-33.

Lian, L. K., \& Tui, L. G. (2012). Leadership styles and organizational citizenship behavior: The mediating effect of subordinates' competence and downward influence tactics. Journal of Applied Business and Economics, 13(2), 59-96.

Mansoor, N., Aslam, H. D., Barbu, C. M., Capusneanu, S., \& Lodhi, M. A. (2012). Organizational structure as determinant of organizational performance: Uncovering essential facets of organic and mechanistic structure. American Journal of Scientific Research, 55(14), 48-55.

Mazloumi, A., Kazemi, Z., Nasl-Saraji, G., \& Barideh, S. (2014). Quality of working life assessment among train drivers in keshesh section of Iran Railway. International Journal of Occupational Hygiene, 6(2), 50-55.

Mckee, J. G. (1991). Leadership styles of community college presidents and faculty job satisfaction. Community/Junior College Quarterly of Research and Practice, 15(1), 33-46.

Mendibil, K., Rudberg, M., Baines, T., \& Errasti, A. (2016). Operations Strategy and Deployment. In Global Production Networks (pp. 82-113). CRC Press.

Menon, M. E. (2014). The relationship between transformational leadership, perceived leader effectiveness and teachers' job satisfaction. Journal of Educational Administration.

Moafimadani, S. K., \& Khalatbari, J. (2019). The relationship between quality of work life and job satisfaction and burnout, with the mediation of emotional intelligence. Journal of Process Engineering, 5(11), 46-66.

Mohamad, M. (2012). A model of quality of work life, life satisfaction and service quality. Asian Journal of Business Research, 2(2), 33-46. 
Mohamad, M., Ab Ghani, N. I., Mamat, M., \& Mamat, I. (2014). Satisfaction as a mediator to the relationships between destination image and loyalty. World Applied Sciences Journal, 30(9), 1113-1123.

Montgomery, D. C. (2017). Design and analysis of experiments. John Wiley \& Sons.

Nguni, S., Sleegers, P., \& Denessen, E. (2006). Transformational and transactional leadership effects on teachers' job satisfaction, organizational commitment, and organizational citizenship behavior in primary schools: The Tanzanian case. School Effectiveness and School Improvement, 17(2), 145-177.

Noblet, A. J., Allisey, A. F., Nielsen, I. L., Cotton, S., LaMontagne, A. D., \& Page, K. M. (2017). The work-based predictors of job engagement and job satisfaction experienced by community health professionals. Health care management review, 42(3), 237-246.

Northouse, P. G. (2018). Leadership: Theory and practice. Sage publications.

Preacher, K. J., \& Hayes, A. F. (2004). SPSS and SAS procedures for estimating indirect effects in simple mediation models. Behavior Research Methods, Instruments, \& Computers, 36(4), 717-731.

Ramawickrama, J., Opatha, H. H. D. N. P., \& PushpaKumari, M. D. (2017). A Synthesis towards the Construct of Job Performance. International Business Research, 10(10), 66-81.

Safavi, H. P., \& Karatepe, O. M. (2018). High-performance work practices and hotel employee outcomes. International Journal of Contemporary Hospitality Management.

Sajtos, L., Snell, L., Sok, P., \& Danaher, T. S. (2015). Achieving growth-quality of work life ambidexterity in small firms. Journal of Service Theory and Practice.

Sanda, A., \& Arthur, N. A. D. (2017). Relational impact of authentic and transactional leadership styles on employee creativity. African Journal of Economic and Management Studies.

Schreiber, J. B., Nora, A., Stage, F. K., Barlow, E. A., \& King, J. (2006). Reporting structural equation modeling and confirmatory factor analysis results: A review. The Journal of Educational Research, 99(6), 323-338.

Sekaran, U., \& Bougie, R. (2016). Research methods for business: A skill building approach. John Wiley \& Sons.

Sethi, G. (2012). Job Satisfaction in Relation to Organizational Citizenship Behavior, Organization Commitment, and WorkFamily Balance. International Journal of Technical Research, 1(2), 5.

Shadraconis, S. (2013). Organizational Leadership in Times of Uncertainty: Is Transformational Leadership the Answer? LUX: A Journal of Transdisciplinary Writing and Research from Claremont Graduate University, 2(1), 28.

Shan, Y., Imran, H., Lewis, P., \& Zhai, D. (2017). Investigating the latent factors of quality of work-life affecting construction craft worker job satisfaction. Journal of Construction Engineering and Management, 143(5), 04016134.

Silins, H., \& Mulford, B. (2002). Leadership and school results. In Second international handbook of educational leadership and administration (pp. 561-612). Springer, Dordrecht.

Sinha, D., \& Shukla, K. S. (2012). Comparative study of job satisfaction of the employees of private and public sector banks. V3 Journal of Management (e-journal), 1(1), 1-96.

Spector, P. E. (1997). Job satisfaction: Application, assessment, causes, and consequences (Vol. 3). Sage publications.

Srivastava, S., Misra, R., \& Madan, P. (2019). 'The Saviors Are Also Humans': Understanding the Role of Quality of Work Life on Job Burnout and Job Satisfaction Relationship of Indian Doctors. Journal of Health Management, 21(2), $210-229$.

Swamy, D. R., Nanjundeswaraswamy, T. S., \& Rashmi, S. (2015). Quality of work life: scale development and validation. International Journal of Caring Sciences, 8(2), 281.

Teixeira, R., Koufteros, X., \& Peng, X. D. (2012). Organizational structure, integration, and manufacturing performance: A conceptual model and propositions. Journal of Operations and Supply Chain Management, 5(1), 70-81.

Turkina, E., Van Assche, A., \& Kali, R. (2016). Structure and evolution of global cluster networks: evidence from the aerospace industry. Journal of Economic Geography, 16(6), 1211-1234.

United States Agency for International Development (USAID) (2018), January 25) APA citation. How and when to reference. Retrieved from https://2012-2017.usaid.gov/sites/default/files/USAID_E-Government_Update_FY2006.pdf

Valaei, N. (2017). Organizational structure, sense making activities and SMËEs' competitiveness. VINE Journal of Information and Knowledge Management Systems.

Van Wyk, A. E., Swarts, I., \& Mukonza, C. (2018). The Influence of the Implementation of Job Rotation on Employees' Perceived Job Satisfaction. International Journal of Business and Management, 13(11), 89-101.

Walumbwa, F. O., Orwa, B., Wang, P., \& Lawler, J. J. (2005). Transformational leadership, organizational commitment, and job satisfaction: A comparative study of Kenyan and US financial firms. Human Resource Development Quarterly, 16(2), 235-256.

World Travel and Tourism Council (WTTC) (2017), January 25) APA citation. How and when to reference. Retrieved from https:/www.wttc.org/-/media/files/reports/economic-impact-research/regions-2017/caribbean2017.pdf

Yukl, G., Gordon, A., \& Taber, T. (2002). A hierarchical taxonomy of leadership behavior: Integrating a half century of behavior research. Journal of Leadership \& Organizational Studies, 9(1), 15-32.

Zikmund, W. G., Carr, J. C., \& Griffin, M. (2013). Business Research Methods (Book Only). Cengage Learning. 
(C) 2020 by the authors; licensee Growing Science, Canada. This is an open access article distributed under the terms and conditions of the Creative Commons Attribution (CC-BY) license (http://creativecommons.org/licenses/by/4.0/). 